\section{Jurnal Mitra Pendidikan (JMP Online)}

URL : http://e-jurnalmitrapendidikan.com

\title{
ANALISIS KOHERENSI PADA WACANA BERITA DENGAN JUDUL KRIM ABAL-ABAL SEBABKAN WANITA DI AS NYARIS KOMA DI LIPUTAN6.COM, JAKARTA
}

\author{
Sugianti \\ Universitas PGRI Wiranegara
}

\section{INFORMASI ARTIKEL}

Dikirim : 13 Juli 2020

Revisi pertama : 22 Juli 2020

Diterima : 24 Juli 2020

Tersedia online : 31 Juli 2020

Kata Kunci: Wacana, Koherensi, Berita

Email: wewangiceria@yahoo.co.id
ABSTRAK

Berita merupakan sebuah informasi terbaru atau informasi mengenai sesuatu yang sedang terjadi. Berita biasanya disajikan melalui bentuk cetak, siaran, internet, atau dari mulut ke mulut kepada orang ketiga dan orang banyak. Berita selalu memuat berbagai topik atau masalah yang ada dilapisan masyarakat. Di dalam berita selalu memuat wacana yang dirangkai melalui kalimat dan membentuk sebuah paragraf.

Penelitian ini bertujuan mempelajari koherensi yang terdapat pada wacana berita. Dalam penyusunan wacana tulis, khususnya berita, koherensi wacana harus diterapkan, analisis ini memiliki hubungan erat dengan bahasa terutama penelitian tentang wacana, salah satunya adalah analisis wacana. Analisis wacana pada penelitian ini adalah analisis koherensi wacana berita dengan judul berita "krim wajah abal-abal sebabkan wanita di AS nyaris koma". Metode dalam menganalisis subyek menggunakan BASIK (baca, simak, dan klasifikasi. Analisis ini dilakukan melalui beberapa tahap, yaitu membaca dan memahami (simak) wacana dengan judul tersebut, dan mengklasifikasi dengan manandai bagian-bagian penting wacana yang berhubungan dengan koherensi. Penganalisisan data dilakukan secara deskriptif.

Ada beberapa hal yang didapat dari hasil penelitian ini, yaitu mengetahui latar belakang wacana dan seluk-beluk tentang koherensi, dan mengetahui beberapa wacana kalimat berita tentang berbagai macam penanda koherensi serta mengetahui keterkaitan antara bagian yang satu dengan bagian yang lainnya, sehingga kalimat tersebut memiliki kesatuan makna yang utuh. 


\section{PENDAHULUAN \\ Latar Belakang}

Berita adalah sajian informasi tentang suatu kejadian yang berlangsung atau kejadian yang sedang terjadi. Penyajian berita dapat dilakukan melalui informasi berantai dari mulut ke mulut atau secara langsung. Ada juga yang menggunakan media, baik media cetak seperti Koran dan majalah maupun media elektronik seperti televisi, radio, dan internet. Penulisan berita di media cetak harus memerhatikan $5 \mathrm{~W}+1 \mathrm{H}$ (what, why, where, who, when, dan how).

Berita menjadi menarik dan memiliki kualitas apabila ditulis berdasarkan fakta dan peristiwa yang telah terjadi sehingga disebut dengan fakta. Kemenarikan suatu berita yang terdapat dalam media cetak dapat dilihat dari judul yang digunakan. Judul berita sangat penting untuk mengantarkan pembaca masuk ke dalam berita. Judul berita digunakan untuk merangkum isi berita kepada pembaca mengenai isi berita. Tapi kali ini saya akan mengkaji unsur koherensi yang terdapat dalam wacana berita. Menurut KBBI koherensi adalah tersusunnya uraian atau pandangan sehingga bagian-bagiannya berkaitan satu dengan yang lain, keselarasan yang mendalam antara bentuk dan isi karya sastra, hubungan logis antara bagian karangan atau antara kalimat dalam satu paragraf, daya tarik antara molekul untuk menghindarkan terpisahnya bagian apabila ada kekuatan dari luar.

\section{Rumusan Masalah}

Merujuk pada latar belakang yang ada di atas, penelitian ini menitikberatkan bagaimana bentuk-bentuk koherensi yang tepat dalam wacana berita dengan judul "Krim Abal-Abal Sebabkan Wanita di As Nyaris Koma di Liputan6.Com, Jakarta" yang dapat diterima oleh pembaca.

\section{Tujuan Penelitian}

Tujuan penulis menganalisis penanda koherensi yang terdapat pada wacana berita yaitu untuk mengetahui pengertian koherensi, implikasinya pada unsur berita, dan juga mengetahui penanda koherensi yang terdapat pada wacana berita. Serta dapat mengetahui penggunaan penanda koherensi tertentu pada wacana berita serta mengetahui keterkaitan antara bagian yang satu dengan bagian yang lainnya, sehingga kalimat tersebut memiliki kesatuan makna yang utuh.

Seperti halnya bahasa, maka wacana pun mempunyai bentuk (form) dan makna (meaning). Kepaduan makna dan kerapian bentuk merupakan faktor penting untuk menentukan tingkat keterbacaan dan keterpahaman wacana. Kohesi merupakan unsur tersurat yang ada dalam wacana. Kerapian (koherensi) merupakan unsur hakikat wacana, unsur yang turut menentukan keutuhan wacana. Dalam kata koherensi, tersirat pengertian pertalian dan hubungan. Jika dikaitkan dengan aspek bentuk dan makna, koherensi kepada aspek makna wacana. Selanjutnya dapat juga dikatakan bahwa koherensi mengacu kepada aspek ujaran.

Ketercapaian pemahaman pembaca dalam suatu wacana tidak pernah lepas dari ketepatan penggunaan penanda koherensi. Wacana yang baik akan meningkatkan persamaan persepsi antara penulis dan pembaca dalam memaknai suatu wacana. 


\section{METODE PENELITIAN \\ Jenis Penelitian}

Penelitian ini menggunakan metode deskriptif. Menurut Moleong (2017: 11) Deskriptif merupakan metode yang didasarkan pada penggunaan data yang berupa kata, gambar, dan bukan sebuah angka. Maka laporan penelitian berisikan kutipan data sebagai gambaran penyajian laporan. Seluruh rangkaian kegiatan penelitian ini, mulai dari penulusuran data hingga proses analisis data, pada akhirnya hasil pemaparan data dan simpulan menggunakan metode deskriptif, yaitu berupa uraian-uraian dan bukan angka. Hasil dan simpulan tersebut mampu menjadi wadah informasi sekaligus memberi manfaat kepada para peneliti lain.

Objek penelitian merupakan apa yang menjadi titik perhatian suatu penelitian. Objek penelitian ini adalah kesalahan berbahasa bidang morfologi dan kesalahan berbahasa bidang sintaksis.

Subjek penelitian adalah subjek yang dituju untuk diteliti oleh peneliti. Subjek penelitian yaitu subjek yang menjadi pusat perhatian atau sasaran peneliti. Subjek dalam penelitian ini adalah wacana berita pada internet yang berjudul "krim wajah abal-abal sebabkan wanita di AS nyaris koma". Analisis data penelitian ini menggunakan metode BASIK (baca, simak, dan klasifikasi).

\section{Baca}

Baca dalam KBBI adalah melihat serta memahami isi dari apa yang tertulis (dengan melisankan atau hanya dalam hati). Kegiatan membaca merupakan kegiatan awal yang dilakukan peneliti dalam sumber data yang utama untuk mencari data berdasarkan berita dari internet. Proses baca ini dilakukan peneliti dalam menganalisis wacana berita ini untuk lebih memahami apa itu berita, apa itu wacana, dan juga seluk-beluk tentang koherensi.

Niknik M. Kuntarto (2013:275) menjelaskan bahwa di dalam kegiatan membaca perlu menerapkan teknik membaca kritis yaitu suatu ketrampilan dalam menemukan sesuatu yang kita cari dalam bacaan. Keberhasilan dalam menerapkan keterampilan membaca kritis bergantung dari sikap, antusias, dan kesiapan kita dalam mempraktikkan.

\section{Simak}

Simak merupakan kegiatan analisis data kedua yang dilakukan oleh peneliti setelah kegiatan membaca kritis dan berulang-ulang. Simak berdasarkan KBBI adalah meninjau (memeriksa, mempelajari) dengan teliti. Simak dalam kaitannya dengan penelitian ini merupakan proses kedua yang dilakukan oleh peneliti untuk memeriksa secara saksama isi wacana berita yang merupakan bahan penelitian.

Menyimak menjadi bagian analisis untuk lebih memperkuat hasil membaca. Proses menyimak ini dilakukan dengan cara memeriksa dan mempelajari sumber data dengan kegiatan mencatat data yang ditemukan dalam wacana berita yang berupa bentuk petanda koherensi dalam wacana. 


\section{Klasifikasi}

Klasifikasi data merupakan proses mengelompokkan data sesuai dengan fokus penelitian yang ingin dicapai. Tahapan ini dilakukan setelah data diklasifikasikan terlebih dahulu sesuai dengan fokus penelitian yang ingin dicapai. Pada tahap ini, data dideskripsikan sesuai dengan teori yang digunakan untuk mengidentifikasi data.

Klasifikasi adalah kegiatan melakukan pengelompokkan penanda koherensi berdasarkan wacana berita yang merupakan sumber data penelitian. Analisis terakhir adalah melakukan klasifikasi data atau pengelompokan berdasarkan penanda koherensi yang ada dalam wacana berita berdasarkan jenis petanda koherensi.

Berdasarkan hasil simak yang berupa catatan tentang penanda koherensi yang ditemukan dalam wacana berita, peneliti melakukan pengkajian terhadap wacana berita dengan judul "krim wajah abal-abal sebabkan wanita di AS nyaris koma". Setelah memahami tentang beberapa hal mendasar tersebut, peneliti merinci yang terkait dalam wacana berita tersebut. Analisis mendasar tersebut ialah menemukan beberapa kalimat yang terdapat dalam berita yang sudah dipilih, hingga kepaduan kalimat tersebut memiliki kesatuan makna yang utuh.

Tujuannya klasifikasi berikutnya untuk mengetahui jenis penanda wacana berita yang merupakan penanda koherensi. Selanjutnya langkah yang digunakan dalam menganlisis wacana berita ini yaitu memilah-milah beberapa kalimat yang terdapat dalam berita tersebut dan memahaminya serta mengetahui arti dari pecahan kalimat tersebut. Setelah mengetahui maksud dari kalimat tersebut, maka menggolongkannya atau mengklasifikan terhadap beberapa penanda koherensi.

\section{KAJIAN PUSTAKA}

\section{Wacana}

Menurut Prof. Dr. Hj. Yoce Aliah Darma, M.Pd (2014:7), Wacana merupakan sekumpulan pernyataan yang dapat diklasifikasikan dalam kategori konseptual tertentu. Wacana merupakan satuan bahasa yang lengkap dalam linguistik yang mengandung konteks sebagai unsur pemaknaannya.

Unsur wacana terdiri dari unsur internal dan eksternal. Unsur internal meliputi kata, kalimat, teks, dan konteks. Sedangkan unsur eksternal dalam wacana meliputi implikatur, presuposisi, referensi, inferensi, dan konteks.

Selain unsur wacana, hal yang ada dalam sebuah wacana adalah prinsip wacana itu sendiri. Prinsip-prinsip tersebut antara lain sebagai berikut.

1. Tujuan

Tujuan sebuah wacana sangat memengaruhi dalam penggunaan teknik penyampaian wacana apakah naratif, deskriptif, eksposisi, argumentasi, ataupun persuasi. 
2. Kohesi

Kohesi merupakan penanda keserasian dalam wacana, yang ditinjau dari hubungan kata, frasa atau kalimat dengan suatu perkataan dalam wacana tersebut.

3. Koherensi

Koherensi merupakan kesinambungan ide yang ada dalam sebuah wacana yang memebentuk pengembangan makna.

4. Sasaran

Sasaran dalam sebuah wacana memengaruhi penggunaan bahasa. Bahasa yang dibuat akan disesuaikan dengan sasaran (pendengar atau pembaca) yang dipilih.

5. Pesan/Isi

Pesan atau isi sebuah wacana merupakan pokok permasalahan yang ingin disampaikan oleh seorang penulis/pembicara kepada sasaran wacana.

6. Keadaan

Pemilihan diksi dan susunan kalimat yang tepat sangat berpengaruh dalam ketercapaian wacana sesuai dengan keadaan.

7. Intereks

Intereks artinya sebuah wacana bergantung kepada wacana yang lain.

Menurut Abdul Chaer (2013:62) wacana merupakan satuan tertinggi yang lengkap terdiri dari konsep, gagasan, pikiran, atau ide yang utuh, yang dapat dipahami dengan jelas dan pasti. Wacana disebut baik jika memenuhi unsur kohesif dan koherensif (Abdul Chaer, 2014:269). Kohesif dan koherensif dapat digunakan dalam berbagai wacana, baik berupa aspek grmatikal maupun aspek semantik.

\section{Analisis Wacana}

Menurut Prof. Dr. Hj. Yoce Aliah Darma, M.Pd (2014:10), Analisis wacana adalah kajian terhadap satuan bahasa yang lebih luas dari kalimat yang memusatkan pada arah yang lebih tinggi dari ketatabahasaan. Dalam ilmu sosiologi, analisis wacana merujuk pada kajian hubungan konteks sosial dengan pemakaian bahasa. Dalam psikologi sosial, analisis wacana merujuk pada struktur dan bentuk percakapan atau wawancara. Sedangkan dalam ilmu politik, analisis wacana menitikberatkan pada bahasa dan kekuasaan. Wacana digunakan dalam kajian apapun, analisis wacana dalam segala aspek kajian tidak lepas dari telaah kebahasaan dalam pemakaiannya.

\section{Koherensi}

Koheren merupakan hubungan perkaitan antarpreposisi yang dinyatakan secara implisit atau tersirat oleh unsur-unsur gramatikal dan semantik dalam kalimat-kalimat pembentuk wacana (Hasan Alwi, 2014: 440). Koherensi dapat juga terlihat berdasarkan unsur-unsur kalimat yang dihubungkan melalui konjungtor.

Untuk memahami koherensi dalam sebuah wacana, diperlukan pemahaman terhadap koherensi dalam sebuah kalmat maupun paragraf. Menurut Widjono (2012:232) koherensi meliputi dalam sebuah kalimat atau paragraph dapat 
dibangun melalui repetisi (pengulangan) kata kunci atau sinonim, kata ganti, kata transisi, dan bentuk paralel.

Beberapa bentuk kohesi melalui konjungtor yang mengikuinya, antara lain: 1) pertentangan yang ditandai dengan konjungtor tetapi atau namun, 2) pengutamaan yang ditandai dengan konjungtor malahan atau bahkan, 3) perkecualian yang ditandai dengan konjungtor keculi, 4) konsesi yang ditandai dengan konjungtor walaupun atau meskipun, dan 5) tujuan yang ditadai dengan konjungtor agar atau supaya.

Menurut Prof. Dr. Hj. Yoce Aliah Darma, M.Pd (2014:7), Koherensi adalah keserasian ide yang ada dalam sebuah wacana yang menghadirkan satu teks yang bermakna.

Menurut Abdul Chaer (2013:62) Koherensi meliputi unsur yang berkaitan dengan aspek semantik, seperti penggunaan hubungan pertentangan, sebab-akibat, perbandingan, dan generic-spesifik.

\section{Berita}

Menurut Dr. H. Mahi M. Hikmat, M.Si (2018:148) berita adalah bentuk karya jurnalistik yang dominan ada pada media massa, terutama media cetak. Namun dengan perkembangan zaman, berita tidak hanya dapat ditemukan pada media massa saja. Melainkan sekarang berita dapat kita peroleh dari media elektronik, seperti televisi, radio, dan gawai.

Dengan perkembangan zaman, gawai kecil yang kita miliki, mampu memberikan berita yang berisi informasi up to date dengan mudah sesuai dengan kebutuhan kita.

Ada delapan konsep rujukan yang dapat dijadikan acuan dalam isi berita, antara lain: 1) berita sebagai laporan tercepat, 2) berita sebagai rekaman (bahan dokumentasi), 3) berita sebagai fakta objktif, 4) berita sebagai interpretasi, 5) berita sebagai sensasi, 6) berita sebagai minat insani, 7) berita sebagai gambaran, dan 8) berita sebagai ramalan.

\section{Liputan6.com}

Liputan6.com merupakan salah satu situs online yang menyajikan beraneka ragam informasi pilihan bagi para penggunanya. Situs ini didirikan oleh PT Kreatif Media Karya pada tanggal 24 Agustus 2000 yang juga merupakan anak perusahaan Elang Mahkota Teknologi.

Liputan6.com merupakan portal berita online yang berdasarkan program SCTV dengan motto menyajikan berita-berita dengan "Aktual, Tajam, dan Terpercaya.

\section{HASIL PENELITIAN DAN PEMBAHASAN \\ Transkrip Wacana Berita}

Liputan6.com, Jakarta Seorang wanita di California, Amerika Serikat, harus dirawat dalam kondisi semikoma usai dilaporkan menggunakan krim wajah. Produk tersebut ternyata tercemar merkuri.

Kejadian tersebut terjadi pada pertengahan September lalu. Departemen Pelayanan Kesehatan Wilayah Sacramento menyatakan bahwa wanita 47 tahun 
ini menggunakan krim wajah merek terkenal, yang dibelinya lewat pihak ketiga yang mengimpor dari Meksiko.

"Ini adalah kasus keracunan metil merkuri yang dilaporkan pertama kali dari jenis ini, terkait dengan krim kulit di Amerika Serikat," kata departemen kesehatan setempat, seperti dikutip dari People pada Senin (31/12/2019).

Pihak perusahaan krim tersebut membantah bahwa produk yang mereka jual tercemar merkuri.

"Kami menangani masalah ini dengan sangat serius dan bekerja sama dengan semua pengecer resmi untuk memastikan produk tetap utuh dan aman untuk digunakan dari pengiriman ke penyimpanan," tulis perusahaan tersebut.

Pihak perusahaan kosmetik itu juga menyatakan pihaknya akan bekerja sama dengan petugas berwenang untuk menyelidiki masalah ini, serta meminta konsumen lebih sadar bahayanya penjualan dan kerusakan produk yang tidak resmi.

Olivia Kasirye dari departemen kesehatan Sacramento meminta agar warga setempat berhenti menggunakan krim kulit serupa yang diimpor dari Meksiko karena risikonya.

"Metil merkuri sangat berbahaya bagi orang dewasa dan anak-anak," ujarnya.

Dikutip dari USA Today, World Health Organization menyatakan bahwa saat metil merkuri dimasukkan dalam produk perawatan kulit, zat tersebut bisa menghentikan produksi melanin dan membuat warna kulit menjadi lebih terang. Namun, mereka bisa menyebabkan ruam, jaringan parut, dan perubahan warna.

Selain itu, National Institutes of Health di AS menyatakan bahwa zat tersebut bisa menyebabkan kebutaan, tuli, dan kerusakan sistem saraf pusat. Keracunan parah tidak bisa disembuhkan.

Berdasarkan hasil penelitian melalui transkrip wacana berita di atas, terdapat penanda koherensi yang digunakan, antara lain sebagai berikut:

Pada kutipan : Kata departemen kesehatan setempat, seperti dikutip dari people pada senin (31/12/2019).

Merupakan penanda koherensi jenis perbandingan (komparasi). Pada kata $\rightarrow$ Seperti, karena membandingkan sesuatu yang sama tetapi tidak serupa.

Pada kutipan : Pihak perusahaan kosmetik itu juga menyatakan pihaknya akan bekerja sama dengan petugas berwenang untuk menyelidiki masalah ini.

Merupakan penanda koherensi jenis tempat (lokasi). Pada kata $\rightarrow$ itu, menunjukkan sebuah lokasi, dimana tempat sebuah perusahaan kosmetik tersebut

Pada kutipan: Meminta agar warga setempat berhenti menggunakan krim kulit serupa yang diimpor dari Meksiko karena risikonya.

Merupakan penanda koherensi jenis perbandingan (komparasi). 
Pada kata $\rightarrow$ serupa, karena kata serupa merupakan sebuah perbandingan suatu hal yang satu dengan yang lain, yang bermakna, agar warga menghindari krim yang sama kemasannya dengan krim yang dimaksud.

Pada kutipan : Metil merkuri sangat berbahaya bagi orang dewasa dan anak-anak Merupakan penanda koherensi jenis kelas anggota.

Pada kata $\rightarrow$ dewasa dan anak-anak, karena menjelaskan bagian umum jika metil sangat berbahaya digunakan oleh orang dewasa, hingga merujuk pada bagian khusus yaitu anak-anak.

Pada kutipan: Membuat warna kulit menjadi terang, namun mereka bisa menyebabkan ruam jaringan parut dan perubahan warna.

Merupakan penanda koherensi jenis pertentangan (kontras).

Pada kata $\rightarrow$ namun, karena menjelaskan akibat dari penggunaan krim yang bertentangan dengan yang diharapkan, awalnya wajah kita putih, namun seiring berjalannya waktu ternyata menyebabkan kulit kita tidak sehat dan rentan mengalami berbagai masalah.

Pada kutipan: Keracunan parah tidak bisa disembuhkan, yang menyebabkan kebutaan, tuli, dan kerusakan sistem saraf pusat.

Merupakan penanda koherensi jenis keseluruhan ke sebagian.

Pada kata $\rightarrow$ parah, kebutaan, tuli, dan kerusakan sistem saraf pusat, karena parah merupakan sebuah inti dari kondisi penyakit yang disebabkan oleh penggunaan krim, hingga menjelaskan bagian tertentu yang terkena dampak dari penggunaan krim tersebut.

Pada kutipan : "Produk tersebut ternyata tercemar merkuri". Kata produk dalam wacana di atas merupakan bentuk koherensi dari krim wajah yang digunakan oleh seorang wanita di AS yang menyebabkan kondisinya semikoma.

Pada kutipan "Kami menangani masalah ini dengan sangat serius dan bekerja sama dengan semua pengecer resmi untuk memastikan produk tetap utuh dan aman untuk digunakan dari pengiriman ke penyimpanan," tulis perusahaan tersebut."

Pada kata "serius" berkaitan dengan proposisi yang dinyatakan oleh pihak produsen yang melakukan kegiatan jual beli produknya dengan baik sesuai standar nasional untuk memastikan kelayakan krim kulit yang dijualnya.

Pada kutipan :"Kami menangani masalah ini dengan sangat serius dan bekerja sama dengan semua pengecer resmi untuk memastikan produk tetap utuh dan aman untuk digunakan dari pengiriman ke penyimpanan," tulis perusahaan tersebut.

Kata "kami" yang terdapat pada kalimat di atas merupakan koherensi "pengganti nama orang". Dalam hal ini adalah nama pihak perusahaan atau produsen dari krim wajah tersebut. 


\section{KESIMPULAN DAN SARAN \\ Kesimpulan}

Berdasarkan hasil analisis yang telah dilakukan, maka peneliti menyimpulkan bahwa unsur penanda koherensi yang paling banyak yaitu perbandingan (komparasi) dengan menemukan dua jenis penanda koherensi di dalam wacana berita tersebut. Koherensi tersebut merupakan penanda jenis tempat (lokasi), kelas ke anggota, pertentangan (kontras) dan keseluruhan ke sebagian, ditemukan masing-masing satu dalam wacana berita tersebut. Karena banyaknya kalimat perbandingan yang ditemukan dalam kalimat tersebut maka dalam wacana berita ini disebut dominan pada penanda koherensi jenis perbandingan (komparasi).

Berdasarkan wacana berita tersebut, hasil penelitian yang dapat peneliti simpulkan adalah bahwa seorang perempuan nyaris koma karena penggunaan krim wajah berbahaya yang ia gunakan. Awalnya krim ini membuat wajah bagus dan terlihat putih bersih, namun seiring berjalannya waktu dalam penggunaan krim ini maka wajah wanita itu mulai meradang dan menimbulkan beberapa masalah kulit diantaranya muncul jaringan parut, menyebabkan ruam atau lebam, bahkan bisa juga mengakibatkan hal yang sangat parah jika digunakan terus menerus, yaitu kebutaan, tuli, bahkan kerusakan sistem saraf pusat. Oleh karena itu kita sebagai wanita harus menjaga wajah kita, karena wajah merupakan asset berharga yang kita miliki, kita harus selektif dalam memilih krim wajah. Bahkan kita bisa mencari tahu komposisi bahan yang digunakan dalam pembuatan krim tersebut. Jika kita menemukan satu komposi yang menurut kita berbahaya, maka harus segera kita hentikan pemakaian krim agar tidak menimbulkan efek samping yang berbahaya bagi kesehatan kita.

Ketepatan penggunaan penanda koherensi dalam wacana berita sangat mendukung kebenaran maksud yang disampaikan oleh penulis dalam isi berita. Sehingga pesan yang disampaikan dapat diterima oleh pembaca. Selain itu, penanda koherensi dalam wacana merupakan kesatuan bahasa yang menjadikan daya tarik atau ciri bahasa seorang penulis yang satu dengan penulis lainnya.

\section{Saran}

Bagi seluruh pembaca diharapkan dapat memahami isi wacana berita dengan benar agar ketepatan maksud yang disampaikan penulis mampu menjadi informasi yang akurat. Sedangkan bagi penulis berita, ketepatan penanda koherensi dalam wacana sangant memengarungi keefektifan bahasa. Mulai dari keefektifan dalam kalimat, paragraf, sampai pada keutuhan wacana yang sangat mendukung pemahaman dan persamaan persepsi antara penulis dan pembaca berita.

\section{DAFTAR PUSTAKA}

Alwi, Hasan. 2014. Tata Bahasa Baju Bahasa Indonesia, cetakan ketiga. Jakarta: Balai Pustaka.

Chaer, Abdul. 2013. Kajian Bahasa: Struktur Internal, Pemakaian, dan Pemelajaran. Jakarta: Rineka Cipta.

Chaer, Abdul. 2014. Linguistik Umum. Jakarta: Rineka Cipta. 
Darma, Yoce Aliyah. 2014. Analisis Wacana Kritis Dalam Multi Perspektif. Bandung: Refika Aditama https://www.liputan6.com/health/read/4144485/krim-wajah-abal-abal-sebabkanwanita-di-as-nyaris-koma. Diakses tanggal 2 Juli 2020.

Hikmat, Mahi M. 2018. Jurnalistik: Literary Journalism. Jakarta: Prenada Group.

Kuntarto, Niknik M. 2013. Cermat dalam Berbahasa Teliti dalam Berfikir. Jakarta: Mitra Wacana Media.

(KBBI online) https://kbbi.web.id/simak.html. Diakses tanggal 2 Juli 2020.

https://id.m.wikipedia.org/wiki/lLiputan6.com. Diakses tanggal 2 Juli 2020.

Moleong, Lexy J. 2017. Metodologi Penelitian Kualitatif. Bandung: Remaja Rosda Karya 